\title{
GENERAL EGG CHARACTERISTICS AND ALTERATION DURING THE EGG- LAYING PERIOD BY GREY PARTRIDGE (Perdix perdix)
}

\author{
Ferenc Jánoska \& Gyula Sándor \\ University of Sopron, Institute of Wildlife Management and Vertebrate Zoology \\ Soproni Egyetem, Vadgazdálkodási és Gerinces Állattani Intézet \\ H-9400 Sopron, Bajcsy-Zs u. 4., Hungary \\ e-mail: janoska.ferenc@uni-sopron.hu
}

\begin{abstract}
JÁNOSKA, F. \& SÁNDOR, G. (2019): GENERAL EGG CHARACTERISTICS AND ALTERATION DURING THE EGG-LAYING PERIOD BY GREY PARTRIDGE (Perdix perdix). Hungarian Small Game Bulletin 14: 171-183. http://dx.doi.org/10.17243/mavk.2019.171

In Hungary, the hand-rearing of winged game, especially pheasant and grey partridge, is a well-known management form of small game management. In the latest decades, the intensive hand-rearing methods are the domineering procedure.

A well-known phenomenon that egg size varies greatly within many avian species. Many kinds of research pointed that variation within species is greatly high but within clutches the flexibility is altered depending on species, clutch size, laying date or sequence of the egg. We have only a few information about winged game species egg mass alterations.

For new information, we manage egg produce stock population in fenced circumstances and these stock populations produce for our investigation hatching eggs. During our investigations we checked the main data of the eggs: laying data, weight, width, length and from these data, we calculated the egg volume and egg shape index as well.

We found in a single clutch the deviation between the smallest and the biggest egg fairly high. We noticed as high as $85.5 \%$ deviation between the largest and the smallest egg mass.

From altogether 35 evaluated breeding pairs, egg mass tendency of 17 pairs showed a stagnant trend during egglaying season. At the same time, from the other 18 breeding pairs, two pairs showed an explicit decreasing, other 16 pairs an explicit growing tendency in egg weight after laying order at a 5\% level $(\mathrm{p}<0.05)$.

These data provide new information about egg production and serve new possibilities for renewing intense technologies of winged game management.
\end{abstract}

KEY WORDS: grey partridge, egg characteristics, egg mass, laying order, precocial species

\section{ÖSSZEFOGLALÁS}

JÁNOSKA, F. \& SÁNDOR, G.: ÁLTALÁNOS TOJÁSMÉRET-JELLEMZÖK ÉS MÉRETVÁLTOZÁSOK A FOGOLY (Perdix perdix) TOJATÁSI IDÖSZAKA SORÁN. Magyarországon a szárnyas apróvad, elsősorban a fácán és a fogoly tenyésztése, közismert formája az apróvad-gazdálkodásnak. Az utóbbi évtizedekben az intenzív tenyésztési eljárások váltak általánossá.

Számos madárfaj esetében közismert, hogy a tojás mérete nagy változatosságot mutat. Számos kutatás igazolta, hogy a fajon belüli változatosság meglehetösen nagy lehet, de a fészekaljon belüli változatosság függ a fajtól, a fészekalj méretétől, a tojásrakás időpontjától és a tojás fészekaljbeli, tojásrakási sorrendjétől. Ugyanakkor meglehetősen kevés információnk van e jelenségről szárnyasvadfajaink esetében.

Mindezek miatt zárttéren tartott fogolyállománytól gyüjtöttünk tojásokat és vizsgáltuk a tojásrakás minden adatát. Feljegyzésre került a fogolypár száma, a tojás keletkezési dátuma, a tojás tömege, szélessége, hosszúsága, majd ez utóbbi két adatból számítottuk a tojás térfogatát és a tojásindexet.

Egy-egy fészekaljon belül viszonylag nagy különbséget detektáltunk a legnagyobb és a legkisebb tojás tekintetében. Szélsőséges esetben a legnagyobb tojás $85,5 \%$-kal volt nagyobb, mint a legkisebb. 
A 35 kiértékelt fogolypár esetében 17 párnál stagnáló tendenciát mutattunk ki a tojásméret változása tekintetében. Ugyanakkor 2 pár esetében szignifikáns csökkenő, 16 pár esetében szignifikáns növekvő tendenciát tapasztaltunk a tojásméret változását illetően $(\mathrm{p}<0.05)$.

Adataink új információkkal szolgálnak a fogoly tojásprodukciójáról és lehetőséget teremtenek a tenyésztési eljárások megújítására is.

KULCSZAVAK: szürke fogoly, tojás adatok, tojás tömeg, megtojás sorrendje, fészekhagyó faj

\section{INTRODUCTION}

In Hungary, the hand-rearing of winged game, especially pheasant and grey partridge, is a well-known form of small game management. In the latest decades, the intensive hand-rearing methods are the domineering procedure (JÁNOSKA, 2016, BAGI et al., 2018). In the 2017 hunting year, more than 600,000 pheasants and about 12000 partridges were released to hunting territories in Hungary, more than $85 \%$ for hunting purposes (CSÁNYI, 2018). During intensive captive rearing, the breeding pairs of grey partridges are usually in the first year of their life. The selected breeding pairs originated from the first artificial hatching of the previous year, that is, the breeding pairs come from the very first eggs of the past capturebreeding population (ANDROVICZ, 2013).

Egg size is a widely studied trait and yet the causes and consequences of variation in this trait remain poorly understood. Egg size varies greatly within many avian species, with the largest egg in a population generally being at least $50 \%$ bigger as the smallest, or even twice as large (CHRISTIANS, 2002). Intraclutch egg size variation is probably a mechanism of female birds to modulate reproductive effort and offspring quality (GIBSON \& WILLIAMS, 2017), especially by altricial bird species. However, different species showing a dissimilar figure of laying-sequence-specific egg size, e.g. Goldcrest, Regulus regulus (HAFTORN, 1986) increase egg size with laying sequence whereas other species (e.g. European Starling, Sturnus vulgaris) decrease egg size with laying order (GIBSON \& WILLIAMS, 2017). At the same time, by other altricial species, researches found no relation between egg mass and position in the laying sequence, e.g. by blue tit (NILSSON \& SVENSSON, 1993).

The brood-reduction hypothesis proposed by LACK (1954, cit. FRIEDL 1993). Lack suggested that, at the time of egg-producing, females usually be impossible to predict food availability during the rearing period. Therefore, females would produce an "optimistic" number of eggs (i.e. as many eggs as young could be reared under optimal environmental conditions). SLAGSVOLD ET AL. (1984) suggested that birds adopting the "brood-reduction strategy" have a small final egg, particularly those birds with large clutches, whereas birds adopting the "brood-survival strategy" have a relatively large final egg, particularly those birds with large clutches.

In many species of passerine birds, egg size increases with the laying order, and this phenomenon is indeed difficult to give a reasonable means of the brood-reduction hypothesis (ClARK \& Wilson, 1981; Slagsvold et al., 1984).

Pheasant and grey partridge are precocial bird species. In precocial species, egg-laying and incubation are important stages of reproductive investment and may perform critical energy bottlenecks, particularly in harsh environment conditions (SHI et al., 2019). MAGRATH (1992) advised that egg mass might have a greater effect on chick survival in precocial than altricial species (with relatively little investment in egg production). It is evident, the mass and composition of an egg have a considerable impact on the successful development of the embryo and may influence the subsequent survival of the hatchling (FINKLER et al., 1998), 
especially in precocial birds. Volume and fresh egg mass are generally highly correlated (REID \& BOERSMA, 1990).

Our target was to analyze the egg characteristics, especially the egg mass alteration during laying period in hand-reared grey partridge, a precocial species characterized by fairly large clutches.

\section{MATERIAL AND METHODS}

Examinations were carried out in four ensuing years (2015-2018) during the reproductive season of grey partridges (March - July) on the Botanical Garden belonging to the University of Sopron. Our breeding stock originated from the very first 150 eggs obtained from Lenes Breeding Farm in 2014. Mean birds were chosen from the gaggle each year for the eggproductive season. During winter months, birds were fed entirely wheat grain. From Mid-February wheat was gradually replaced by complete nutrition which contained: $16,4 \%$ crude protein and 11.05 MJ ME and $2.49 \%$ calcium, so that by March 1st, it was the only feed, fed ad libitum.

Partridge pairs were placed in open-air wire cages $(1 \times 1 \mathrm{~m}$, respectively). Breeding pairs of partridges we formed about Mid-March. We investigated 21, 6, 16, 12 breeding pairs of grey partridges in 2015-2018, respectively. From these breeding populations, yearly 12, 3, 9 and 11 pairs produced more than 15 eggs/breeding season, so we used in our analysis only the results of these pairs.

When hens started laying we gathered the eggs by late afternoon each day. We marked each egg with a non-toxic permanent marker pen (date of laying, the number of partridge hen). Additionally, we collected eggs in two other breeding farms in Hungary in 2016. In Kecel Breeding Farm we measured 47 eggs from 10 breeding pairs, in Lenes Breeding Farm 101 eggs form 20 breeding pairs (between 15-22th April, respectively). Because of the methods of egg-producing, we have exact data from each partridge female eggs.

Just after collection eggs were weighed to the nearest $0.01 \mathrm{~g}$ with a digital balance. Egg breadth and length we measured with a digital caliper to the nearest $0.01 \mathrm{~mm}$. Egg volume we calculated with the method of HOYT (1979) from the length and breadth of the egg, with some little modification based on our previous research (JÁNOSKA unpubl.). We measured altogether 1515 partridge eggs.

We investigated the relationship between laying order, egg weight, and egg volume. Linear correlation analysis has been used in examining the characteristics of eggs.

\section{RESULTS AND DISCUSSION}

\subsection{GENERAL EGG CHARACTERISTICS}

The egg dimensions (Table 1) correspond to the data of literature. In some oological collections measured 358 partridge eggs FARAGÓ (2001) in Hungary. He found the average egg is $35.10 \times 26.78 \mathrm{~mm}$. In former Czechoslovakia the average egg was found $(\mathrm{N}=222)$ 34.99 X $26.45 \mathrm{~mm}$ (GluTZ et al., 1973, cit. FARAGÓ 2001). After 13 clutches, altogether 183 eggs found the average egg $34.58 \times 26.48 \mathrm{~mm}$ CAROLL et al., (2020). 
Table 1: The egg characteristics (2015-2018)

1.táblázat: A tojások legfontosabb adatai

\begin{tabular}{|c|c|c|c|c|c|}
\hline & $\mathrm{N}$ & Mean & SD & Maximum & Minimum \\
\hline Fresh egg weight $(\mathrm{g})$ & 1515 & 13.44 & 1.194 & 17.66 & 7.40 \\
\hline Length $(\mathrm{mm})$ & 1515 & 34.48 & 1.458 & 37.98 & 27.29 \\
\hline Width $(\mathrm{mm})$ & 1515 & 26.67 & 0.891 & 29.07 & 21.81 \\
\hline Volume $\left(\mathrm{cm}^{3}\right)$ & 1515 & 12.37 & 1.195 & 15.877 & 6.73 \\
\hline Shape index & 1515 & 77.439 & 2.561 & 88.777 & 68.057 \\
\hline
\end{tabular}

The following Table 2-5 we gathered the most important data for each year investigated. Every year except 2016 there were breeding pairs produced no eggs. Some earlier investigations report a similar situation, namely the egg production of gray partridge is erratic (MULLER et al., 1971, CSÁNYI, 1993). The reasons are not sufficiently clear; CSÁNYI (1993) suggested it is a natural phenomenon and affects 6-9\% of the artificial breeding population. From our other studies, we hypothesize that some birds do not reach sexual maturity in their first year of life. In our studies with Reeves's pheasants (Syrmaticus reevesii), we found in several cases that the male became sexually mature only in his second year of life (JÁNOSKA unpubl.).

Table 2: Egg weight data in 2015

2. táblázat: A tojások tömegadatai, 2015

\begin{tabular}{|c|c|c|c|c|c|c|c|}
\hline $\begin{array}{c}\text { No of } \\
\text { breeding } \\
\text { box }\end{array}$ & $\mathrm{N}$ & $\begin{array}{c}\text { Mean } \\
\text { weight, } \mathrm{g}\end{array}$ & $\mathrm{SD}$ & $\begin{array}{c}\text { Maximum, } \\
\mathrm{g}\end{array}$ & $\begin{array}{c}\text { Deviation } \\
\text { from the } \\
\text { mean, \% }\end{array}$ & $\begin{array}{c}\text { Minimum, } \\
\mathrm{g}\end{array}$ & $\begin{array}{c}\text { Deviation } \\
\text { from the } \\
\text { mean, \% }\end{array}$ \\
\hline 1 & 30 & 13.80 & 0.750994 & 15.14 & 9.71 & 12.31 & -10.81 \\
\hline 2 & 24 & 13.51 & 1.079223 & 16.08 & 19.02 & 12.00 & -11.18 \\
\hline 3 & 18 & 14.23 & 1.409873 & 15.71 & 10.40 & 11.87 & -16.58 \\
\hline 4 & 28 & 13.38 & 0.944669 & 15.11 & 12.95 & 11.13 & -16.82 \\
\hline 5 & 30 & 13.80 & 1.056668 & 16.98 & 23.04 & 11.49 & -16.74 \\
\hline 6 & 15 & 13.79 & 1.134527 & 15.89 & 15.26 & 11.81 & -14.38 \\
\hline 7 & 3 & 12.71 & 0.390366 & 13.15 & 3.49 & 12.20 & -3.99 \\
\hline 8 & 24 & 13.12 & 0.883679 & 15.12 & 15.26 & 11.30 & -13.87 \\
\hline 9 & 13 & 12.75 & 0.596174 & 13.92 & 9.18 & 11.46 & -10.12 \\
\hline 10 & 0 & 0 & 0 & 0 & 0 & 0 & 0 \\
\hline 11 & 0 & 0 & 0 & 0 & 0 & 0 & 0 \\
\hline 12 & 24 & 13.50 & 1.029118 & 15.76 & 16.74 & 11.82 & -12.44 \\
\hline 13 & 7 & 13.96 & 0.365156 & 14.70 & 5.30 & 13.52 & -3.15 \\
\hline 14 & 32 & 13.45 & 0.757742 & 15.51 & 15.32 & 11.73 & -12.81 \\
\hline 15 & 9 & 14.01 & 0.619428 & 14.87 & 6.14 & 12.78 & -8.78 \\
\hline 16 & 0 & 0 & 0 & 0 & 0 & 0 & 0 \\
\hline 17 & 8 & 13.08 & 0.444075 & 13.80 & 5.50 & 12.56 & -3.98 \\
\hline 18 & 0 & 0 & 0 & 0 & 0 & 0 & 0 \\
\hline 19 & 15 & 13.39 & 0.738034 & 15.44 & 15.33 & 12.35 & -7.77 \\
\hline 20 & 33 & 12.87 & 1.331249 & 15.29 & 18.80 & 8.24 & -35.98 \\
\hline 21 & 23 & 14.03 & 0.676932 & 15.16 & 8.07 & 12.41 & -11.56 \\
\hline & & & & & & & \\
\hline
\end{tabular}


We found in a single clutch the deviation between the smallest and the biggest egg fairly high. After a wide literature review, CHRISTIANS (2002) found great variability in egg size, but approximately $70 \%$ of the variation in egg mass was due to variation between rather than within clutches, although there were some cases of extreme intra-clutch egg-size variation. The greatest variability in egg size within a single clutch showed in the crested penguins (Eudyptes spp.) that exhibit extreme egg-size dimorphism, with differences of $30 \pm 60 \%$ between eggs (WILLIAMS, 1990; ST. ClAIR, 1996). In contrast, in some partridge females, we found a similar extreme difference between the smallest and largest egg size. For example, in 2015 by the 20th breeding pair, the smallest and the largest egg were $8.24 \mathrm{~g}$ and $15.29 \mathrm{~g}$, respectively. That means an $85.5 \%$ difference (Table 2). Also was the difference fairly high in 2017 by the 3 rd breeding pair (7.40g vs. $11.26 \mathrm{~g}, 52.2 \%$, Table 4).

Table 3: Egg weight data in 2016

3. táblázat: A tojások tömegadatai, 2016

\begin{tabular}{|c|c|c|c|c|c|c|c|}
\hline $\begin{array}{c}\text { No of } \\
\text { breeding } \\
\text { box }\end{array}$ & $\mathrm{N}$ & $\begin{array}{c}\text { Mean } \\
\text { weight, } \mathrm{g}\end{array}$ & $\mathrm{SD}$ & $\begin{array}{c}\text { Maximum, } \\
\mathrm{g}\end{array}$ & $\begin{array}{c}\text { Deviation } \\
\text { from the } \\
\text { mean, \% }\end{array}$ & $\begin{array}{c}\text { Minimum, } \\
\mathrm{g}\end{array}$ & $\begin{array}{c}\text { Deviation } \\
\text { from the } \\
\text { mean, \% }\end{array}$ \\
\hline 1 & 3 & 12.84 & 0.769949 & 13.48 & 4.98 & 11.76 & -8.41 \\
\hline 2 & 31 & 15.13 & 0.845269 & 16.87 & 11.50 & 12.94 & -14.47 \\
\hline 3 & 6 & 11.77 & 0.897863 & 12.71 & 7.99 & 10.08 & -14.36 \\
\hline 4 & 4 & 13.42 & 1.60295 & 15.27 & 13.79 & 10.97 & -18.26 \\
\hline 5 & 29 & 13.08 & 0.814888 & 14.93 & 14.14 & 10.76 & -17.74 \\
\hline 6 & 33 & 13.52 & 0.487851 & 14.64 & 8.28 & 12.46 & -7.84 \\
\hline
\end{tabular}

Table 4: Egg weight data in 2017

4. táblázat: A tojások tömegadatai, 2017

\begin{tabular}{|c|c|c|c|c|c|c|c|}
\hline $\begin{array}{c}\text { No of } \\
\text { breeding } \\
\text { box }\end{array}$ & $\mathrm{N}$ & $\begin{array}{c}\text { Mean } \\
\text { weight, } \mathrm{g}\end{array}$ & $\mathrm{SD}$ & $\begin{array}{c}\text { Maximum, } \\
\mathrm{g}\end{array}$ & $\begin{array}{c}\text { Deviation } \\
\text { from the } \\
\text { mean, \% }\end{array}$ & $\begin{array}{c}\text { Minimum, } \\
\mathrm{g}\end{array}$ & $\begin{array}{c}\text { Deviation } \\
\text { from the } \\
\text { mean, \% }\end{array}$ \\
\hline 1 & 0 & 0 & 0 & 0 & 0 & 0 & 0 \\
\hline 2 & 0 & 0 & 0 & 0 & 0 & 0 & 0 \\
\hline 3 & 40 & 9.82 & 0.82881 & 11.26 & 14.66 & 7.40 & -24.64 \\
\hline 4 & 27 & 13.90 & 0.390965 & 14.61 & 5.11 & 13.04 & -6.19 \\
\hline 5 & 35 & 15.29 & 0.492767 & 16.09 & 5.23 & 14.29 & -6.54 \\
\hline 6 & 14 & 14.42 & 0.425365 & 15.08 & 4.58 & 13.70 & -4.99 \\
\hline 7 & 46 & 13.97 & 0.444719 & 15.00 & 7.37 & 13.24 & -5.23 \\
\hline 8 & 23 & 12.87 & 0.862019 & 14.09 & 9.48 & 10.85 & -15.70 \\
\hline 9 & 19 & 13.96 & 0.466339 & 14.63 & 4.80 & 12.65 & -9.38 \\
\hline 10 & 13 & 12.10 & 0.779274 & 13.19 & 9.01 & 10.67 & -11.82 \\
\hline 11 & 0 & 0 & 0 & 0 & 0 & 0 & 0 \\
\hline 12 & 19 & 13.12 & 0.414288 & 13.79 & 5.11 & 12.29 & -6.33 \\
\hline 13 & 0 & 0 & 0 & 0 & 0 & 0 & 0 \\
\hline 14 & 29 & 14.82 & 0.732554 & 16.48 & 11.20 & 12.91 & -12.89 \\
\hline 15 & 23 & 13.9 & 0.609979 & 14.74 & 6.04 & 12.36 & -11.08 \\
\hline 16 & 12 & 12.25 & 0.370843 & 12.81 & 4.57 & 11.73 & -4.24 \\
\hline
\end{tabular}


However, in both cases, the lightest two eggs were the very first eggs in the clutch $(8.24 \mathrm{~g}$ and $11.09 \mathrm{~g} ; 7.40 \mathrm{~g}$ and $8.21 \mathrm{~g}$, respectively). Following research done with the herring gull, PARSONS (1976) hypothesized that an increase in physiological efficiency of the ovaries and oviduct as development passes from the first egg to the following ones may account for the increase in size between the first egg and subsequent ones. Examining the nesting of the Canada goose, LEBLANC (1987) stated: once the optimal level of efficiency has been attained, eggs could be very similar in size; this was the case in most clutches of grey partridge in our investigations.

Table 5: Egg weight data in 2018

5. táblázat: A tojások tömegadatai, 2018

\begin{tabular}{|c|c|c|c|c|c|c|c|}
\hline $\begin{array}{c}\text { No of } \\
\text { breeding } \\
\text { box }\end{array}$ & $\mathrm{N}$ & $\begin{array}{c}\text { Mean } \\
\text { weight, g }\end{array}$ & $\mathrm{SD}$ & $\begin{array}{c}\text { Maximum, } \\
\mathrm{g}\end{array}$ & $\begin{array}{c}\text { Deviation } \\
\text { from the } \\
\text { mean, \% }\end{array}$ & $\begin{array}{c}\text { Minimum, } \\
\mathrm{g}\end{array}$ & $\begin{array}{c}\text { Deviation } \\
\text { from the } \\
\text { mean, \% }\end{array}$ \\
\hline 1 & 39 & 13.31 & 0.811813 & 15.36 & 15.40 & 11.93 & -10.37 \\
\hline 2 & 47 & 13.11 & 0.919159 & 14.97 & 14.19 & 11.18 & -14.72 \\
\hline 3 & 54 & 15.28 & 0.774652 & 17.66 & 15.58 & 13.01 & -14.86 \\
\hline 4 & 52 & 13.66 & 0.810438 & 16.55 & 21.16 & 12.34 & -9.66 \\
\hline 5 & 71 & 13.41 & 0.509476 & 14.66 & 9.32 & 12.1 & -9.77 \\
\hline 6 & 23 & 13.73 & 0.773271 & 14.67 & 6.85 & 11.54 & -15.95 \\
\hline 7 & 44 & 11.63 & 0.714645 & 14.08 & 21.07 & 10.37 & -10.83 \\
\hline 8 & 0 & 0 & 0 & 0 & 0 & 0 & 0 \\
\hline 9 & 37 & 13.09 & 0.370129 & 14.04 & 7.26 & 12.38 & -5.42 \\
\hline 10 & 20 & 12.68 & 0.925157 & 14.49 & 14.27 & 10.7 & -15.62 \\
\hline 11 & 66 & 13.73 & 0.578476 & 15.16 & 10.42 & 12.56 & -8.52 \\
\hline 12 & 22 & 11.53 & 0.573505 & 12.48 & 8.24 & 10.18 & -11.71 \\
\hline
\end{tabular}

\subsection{Alteration OF EgG MASS AND VOLUME}

From 55 breeding pairs, we appraised 35 pairs produced more than 15 eggs in an eggproducing season. From altogether 35 evaluated breeding pairs, egg mass tendency of 17 pairs showed a stagnant trend during egg-laying season. At the same time, from the other 18 breeding pairs, two pairs showed an explicit decreasing, other 16 pairs an explicit growing tendency in egg weight after laying order at a $5 \%$ level $(\mathrm{p}<0.05)$.

In the first research year (2015) we could evaluate 11 pairs from altogether 21 breeding pairs. From this 11 pairs egg mass of 1 pair showed significantly decreasing, 6 pairs significantly increasing tendency, according to the laying order (Table 6).

In the second research year (2016) we could evaluate 3 pairs from altogether 6 breeding pairs. From these 3 pairs, egg mass of 1 pair showed significantly increasing tendency, according to the laying order (Table 7).

In the third research year (2017) we could evaluate 9 pairs from altogether 16 breeding pairs. From these 9 pairs, egg mass of 6 pairs showed significantly increasing tendency, according to the laying order (Table 8, Figure 3-4).

In the fourth research year (2018) we could evaluate 11 pairs from altogether 12 breeding pairs. From these 11 pairs egg mass of 1 pair showed significantly decreasing, 3 pairs significantly increasing tendency, according to the laying order (Table 9, Figure 1-2). 
Table 6: Egg mass alteration statistical test, 2015

6. táblázat: Tojástömeg-változás statisztikai próbája, 2015

\begin{tabular}{|c|c|c|c|}
\hline 2015 & $\mathrm{~N}$ & $\begin{array}{c}\text { statistically } \\
\text { proven }\end{array}$ & tendency \\
\hline 1 & 30 & NS & increasing \\
\hline 2 & 24 & $\mathbf{S}$ & increasing \\
\hline 3 & 18 & $\mathbf{S}$ & decreasing \\
\hline 4 & 28 & NS & decreasing \\
\hline 5 & 30 & $\mathbf{S}$ & increasing \\
\hline 6 & 15 & NS & increasing \\
\hline 7 & 3 & i.d. & \\
\hline 8 & 24 & $\mathbf{S}$ & increasing \\
\hline 9 & 13 & i.d. & \\
\hline 10 & 0 & n.d. & \\
\hline 11 & 0 & n.d. & \\
\hline 12 & 24 & NS & increasing \\
\hline 13 & 7 & i.d. & \\
\hline 14 & 32 & $\mathbf{S}$ & increasing \\
\hline 15 & 9 & i.d. & \\
\hline 16 & 0 & n.d. & \\
\hline 17 & 8 & i.d. & \\
\hline 18 & 0 & n.d. & \\
\hline 19 & 15 & $\mathbf{S}$ & increasing \\
\hline 20 & 33 & $\mathbf{S}$ & increasing \\
\hline 21 & 23 & NS & increasing \\
\hline
\end{tabular}

S: significant in 5\% level

NS: non-significant

n.d.: no data

i.d.: insufficient data

Table 7: Egg mass alteration statistical test, 2016

7. táblázat: Tojástömeg-változás statisztikai próbája, 2016

\begin{tabular}{|c|c|c|c|}
\hline 2016 & $\mathrm{~N}$ & $\begin{array}{c}\text { statistically } \\
\text { proven }\end{array}$ & tendency \\
\hline 1 & 3 & i.d. & \\
\hline 2 & 31 & S & increasing \\
\hline 3 & 6 & i.d. & \\
\hline 4 & 4 & i.d. & \\
\hline 5 & 29 & NS & increasing \\
\hline 6 & 33 & NS & increasing \\
\hline
\end{tabular}

S: significant in $5 \%$ level

NS: non-significant

i.d.: insufficient data 
Table 8: Egg mass alteration statistical test, 2017

8. táblázat: Tojástömeg-változás statisztikai próbája, 2017

\begin{tabular}{|c|c|c|c|}
\hline 2017 & N & $\begin{array}{c}\text { statistically } \\
\text { proven }\end{array}$ & tendency \\
\hline 1 & 0 & n.d. & \\
\hline 2 & 0 & n.d. & \\
\hline 3 & 40 & S & increasing \\
\hline 4 & 27 & NS & increasing \\
\hline 5 & 35 & NS & decreasing \\
\hline 6 & 14 & i.d. & \\
\hline 7 & 46 & NS & increasing \\
\hline 8 & 23 & S & increasing \\
\hline 9 & 19 & S & increasing \\
\hline 10 & 13 & i.d. & \\
\hline 11 & 0 & n.d. & \\
\hline 12 & 19 & S & increasing \\
\hline 13 & 0 & n.d. & \\
\hline 14 & 29 & S & increasing \\
\hline 15 & 23 & S & increasing \\
\hline 16 & 12 & i.d. & \\
\hline
\end{tabular}

S: significant in $5 \%$ level

NS: non-significant

n.d.: no data

i.d.: insufficient data

Table 9: Egg mass alteration statistical test, 2018

9. táblázat: Tojástömeg-változás statisztikai próbája, 2018

\begin{tabular}{|c|c|c|c|}
\hline 2018 & N & $\begin{array}{c}\text { statistically } \\
\text { proven }\end{array}$ & tendency \\
\hline 1 & 39 & S & increasing \\
\hline 2 & 47 & S & increasing \\
\hline 3 & 54 & NS & increasing \\
\hline 4 & 52 & NS & decreasing \\
\hline 5 & 71 & NS & increasing \\
\hline 6 & 23 & S & increasing \\
\hline 7 & 44 & NS & increasing \\
\hline 8 & 0 & n.d. & \\
\hline 9 & 37 & NS & increasing \\
\hline 10 & 20 & NS & increasing \\
\hline 11 & 66 & NS & increasing \\
\hline $\begin{array}{l}\text { 11 } \\
\text { 12 }\end{array}$ & 22 & S & decreasing \\
\hline $\begin{array}{l}\text { S: significant in 5\% level } \\
\text { n.d.: no data }\end{array}$ & & \\
\hline
\end{tabular}




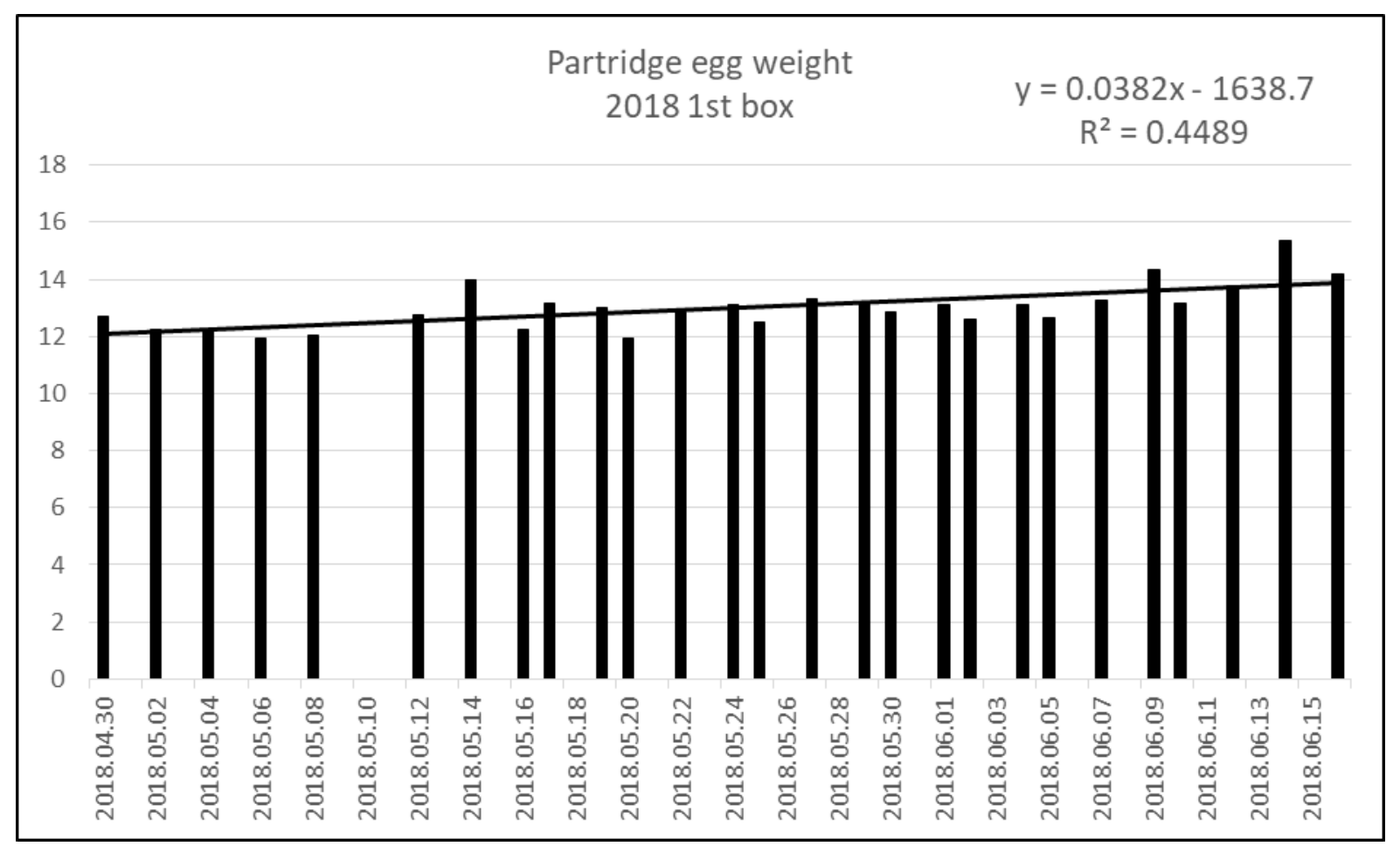

Figure 1: Egg weight alteration in 2018, 1st breeding box 1. ábra: A tojástömeg változása 2018-ban az 1. boxban

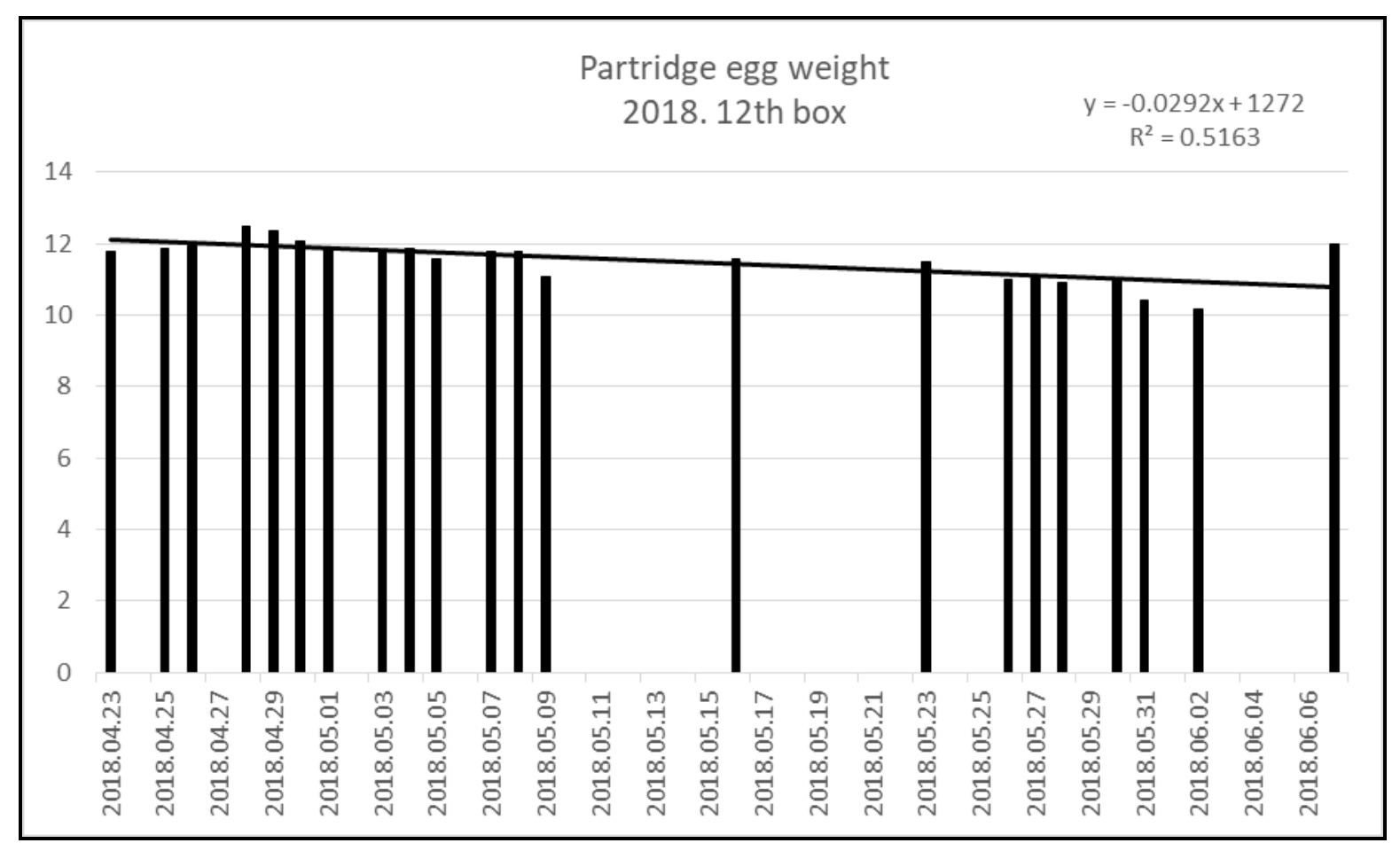

Figure 2: Egg weight alteration in 2018, 12th breeding box

2. ábra: A tojástömeg változása 2018-ban a 12. sorszámú boxban 


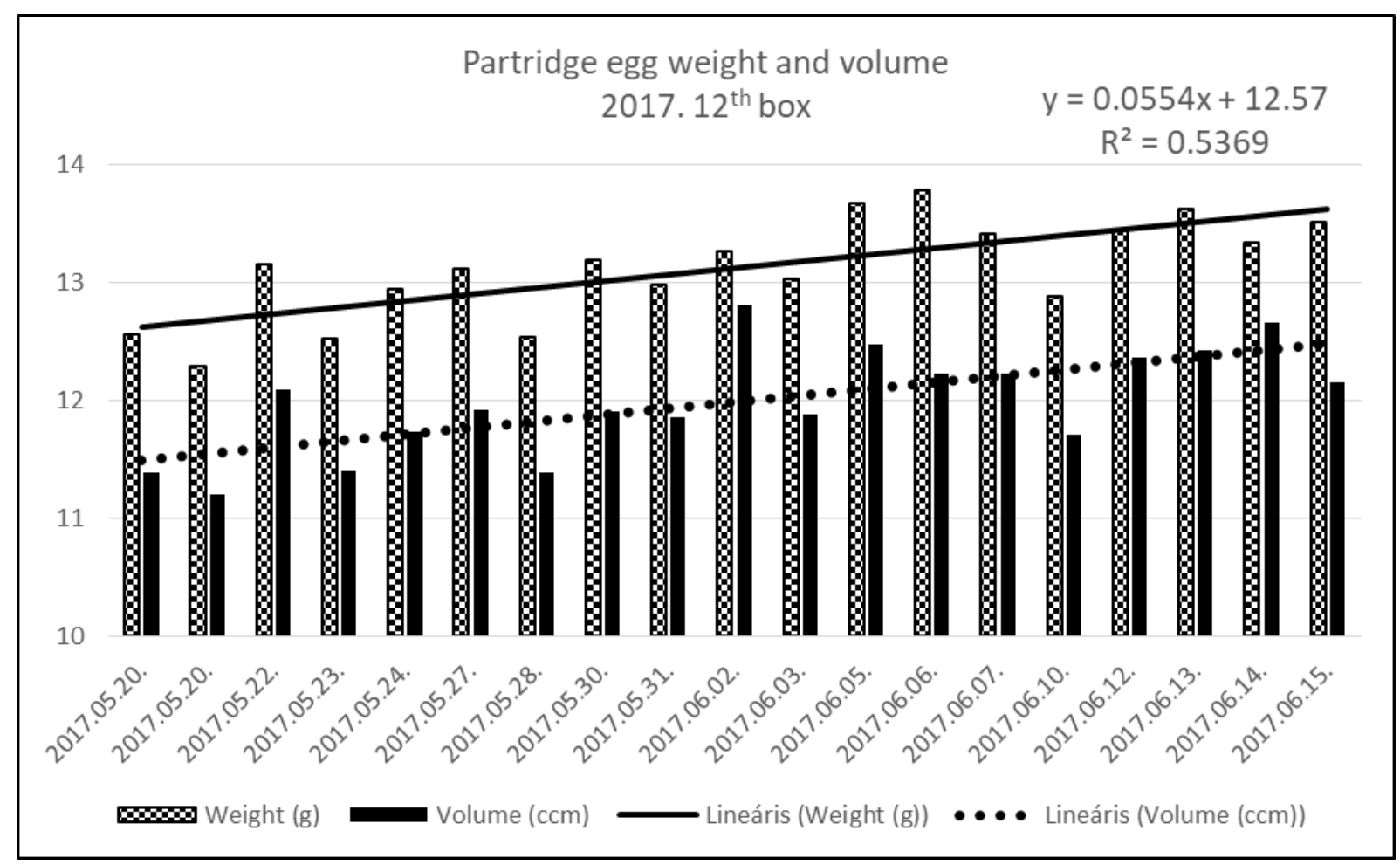

Figure 3: Egg weight and egg volume alteration in 2017, 12th breeding box

3. ábra: A tojástömeg és a térfogat változása 2017-ben a 12. sorszámú boxban

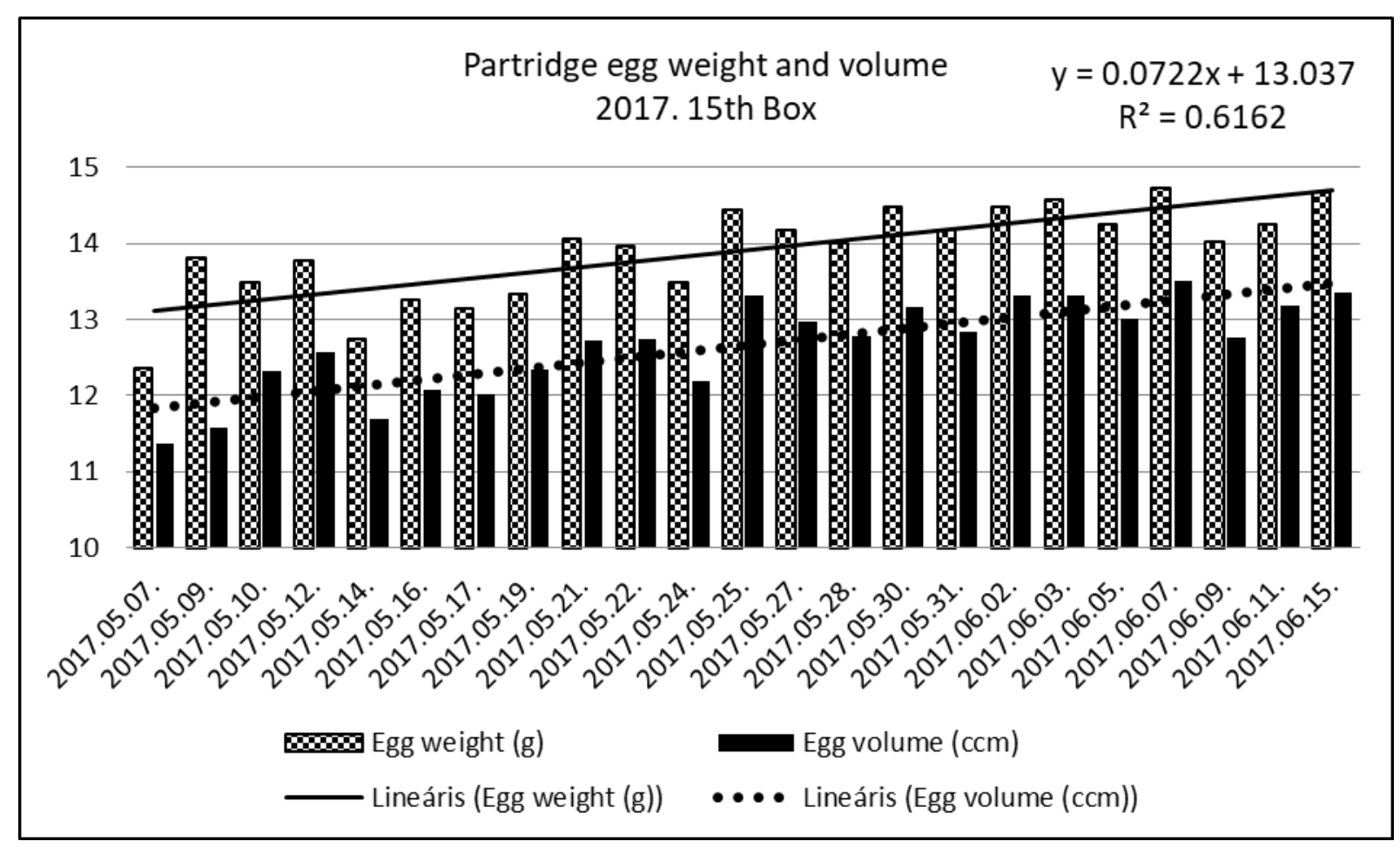

Figure 4: Egg weight and egg volume alteration in 2017, 15th breeding box 4. ábra: A tojástömeg és a térfogat változása 2017-ben a 15. sorszámú boxban 
Because egg volume and fresh egg mass are generally highly correlated (REID \& Boersma, 1990), we can see this phenomenon in Figure 3-4, too.

In the literature, there are only a few data about egg mass alteration within years by partridge species. Variation in egg mass and the period between eggs within years was attributable more to variation among individual females by red-legged partridge (Alectoris rufa), after CABEZAS-DíAZ et al., (2005). In some Italian research with grey partridge (CUCCO et al., 2010), egg characteristics were unrelated to egg position in the laying order, but in this research were measured only the first 20 eggs of each hen.

Investigated the laying gaps by grey partridge, the egg position in the laying order was significantly related to several egg characteristics. In particular, along the laying sequence, there was a significant decrease in egg mass (CUCCO et al., 2017). It has to be noted, they used only the 4th - 20th eggs because the 1st - 3rd eggs are usually low in quality and last-laid eggs are outside of the range occurring in natural positions (CUCCO et al., 2017; POTTS, 1986).

With an increase in egg mass, the most notable increase in component mass was that of albumen, constituting approximately $77 \%$ of the increase in initial egg mass. Yolk and shell constituted roughly $19 \%$ and $4 \%$ of the initial egg mass increase, respectively (FINKLER et al., 1998). It is accepted that in the domestic hens, the eggs' weight increases by the progress in the production period as a result of a decrease in laying and changes in egg formation rate (OTWINOSKA-Mindur et al., 2016). But, in our investigation, we did not find the same reasons.

In a common precocial species, the Lapwing (Vanellus vanellus) egg quality and chick survival rate were studied in southwestern Sweden (BLOMQUIST et al., 1997). They found egg size did not affect chick survival independently of parental quality. The correlation between brood survival and egg volume was significant only for first clutches, suggesting that other factors than egg size were important for chick survival in replacement clutches (BLOMQUIST et al., 1997). It seems in egg production of grey partridge also shows a similar pattern than lapwing.

Data on the breeding biology of geese support the idea that the brood-reduction hypothesis, which was previously discussed in relation to altricial birds, can be applied to geese and perhaps other precocial species (FRIEDL, 1993).

\section{CONCLUSIONS}

We found in a single clutch the deviation between the smallest and the biggest egg fairly high. We noticed as high as $85.5 \%$ deviation between the largest and the smallest egg mass.

From altogether 35 evaluated breeding pairs, egg mass tendency of 17 pairs showed a stagnant trend during egg-laying season. At the same time, from the other 18 breeding pairs, two pairs showed an explicit decreasing, other 16 pairs an explicit growing tendency in egg weight after laying order at $5 \%$ level $(\mathrm{p}<0.05)$. This data is a novel approach of egg-laying investigations in a precocial bird species, the grey partridge.

In the next period of our investigations, we plan to examine the composition data of the eggs laid in different periods during the egg production period.

Further investigations required to find other tendencies on egg production of grey partridge, starting from the related literature cited. 


\section{ACKNOWLEDGMENTS}

This article was made in frame of the „EFOP-3.6.1-16-2016-00018 - Improving the role of research+development+innovation in the higher education through institutional developments assisting intelligent specialization in Sopron and Szombathely".

\section{REFERENCES}

ANDROVICZ, A. (2013): Zárttéri fogolytenyésztés értékmérő tulajdonságainak vizsgálata/ Analysis of plummet attributions at partridge rearing. BSc Thesis work, Sopron (in Hungarian)

BAgI, Z., DAnKu, B. \& KuszA, Sz. (2018): Tenyésztett vadászfácán (Phasianus colchicus) kakasokkal szemben támasztott piaci igények felmérése és értékméröik fejlesztésének lehetöségei/ Assessment of market demands of Pheasant (Phasianus colchicus) cocks and opportunities for developing their production traits. Acta Agronomica Óváriensis 59(1): 82-105.

BlomQuist, D., JOHANSSON, O.C. \& GöTMARK, F. (1997): Parental quality and egg size affect chick survival in a precocial bird, the lapwing Vanellus vanellus. Oecologia 110: 18-24. https://doi.org/10.1007/s004420050128

CABEZAS-DíAZ, S., VIRGÓS, E. \& VILLAFUERTE, R. (2005): Reproductive performance changes with age and laying experience in the Red-legged Partridge Alectoris rufa. Ibis 147: 316-323. https://doi.org/10.1111/j.1474-919x.2005.00406.x

Carroll, J. P., McGowan, P.J.K., \& KIRWAN, G.M. (2020): Gray Partridge (Perdix perdix), version 1.0. In Birds of the World (S. M. Billerman, Editor). Cornell Lab of Ornithology, Ithaca, NY, USA. doi: https://doi.org/10.2173/bow.grypar.01

Christians, J.K. (2002): Avian egg size: variation within species and inflexibility within individuals. Biologian Review 77: 1-26. https://doi.org/10.1017/S1464793101005784

Clark, A.B. \& WILSON, D.S. (1981): Avian breeding adaptations: Hatching asynchrony, brood reduction, and nest failure. The Quarterly Review of Biology 56: 253-277. https://doi.org/10.1086/412316

CsÁNYI, S. (1993): A szürkefogoly (Perdix perdix L.) zárttéri tenyésztése Gödöllön 19651976 [Artificial breeding of gray partridge in Gödöllö between 1965-1976]. Erdészettörténeti Közlemények 10: 81-98. (in Hungarian)

CsÁNYI, S., ed. (2018): Vadgazdálkodási Adattár - 2017/2018. vadászati év. Országos Vadgazdálkodási Adattár [Hungarian Game Management Database], Gödöllö: 58. (in Hungarian)

Cucco, M., Pellegrino, I. \& Malacarne, G. (2010): Immune challenge affects female condition and egg size in the grey partridge. Journal of Experimental Zoology 313A: 597-604. https://doi.org/10.1002/jez.635

Cucco, M., Grenna, M. \& Pellegrino, I. (2017): Egg characteristics in relation to skipped days of laying in the Grey Partridge. Avian Biology Research 10(4): 231-240. https://doi.org/10.3184/175815617X15036738758853

FARAGÓ, S. (2001): Adatok a magyarországi mezei szárnyasvadfajok fészekalj nagyságaihoz és tojásméreteihez [Contribution of data to the clutch and egg size of field gme bird species in Hungary]. Magyar Apróvad Közlemények 6: 113-132. (In Hungarian with English summary)

FINKLER, M.S., VAN ORMAN, J.B. \& SOTHERLAND, P.R. (1998): Experimental manipulation of egg quality in chickens: influence of albumen and yolk on the size and body 
composition of near-term embryos in a precocial bird. Journal of Comp Physiology B 168: 17-24. https://doi.org/10.1007/s003600050116

FRIEDL, T.W.P. (1993): Intraclutch Egg-Mass Variation in Geese: A Mechanism for Brood Reduction in Precocial Birds? The Auk 110(1): 129-132.

GiBSON, K.F. \& WILLIAMS, T.D. (2017): Intraclutch egg size variation is independent of ecological context among years in the European Starling Sturnus vulgaris. Journal of Ornitology 158: 1099-1110. https://doi.org/10.1007/s10336-017-1473-4

HAFTORN, S. (1986): Clutch size, intraclutch egg size variation, and breeding strategy in the Goldcrest Regulus regulus. Journal of Ornitology 127(3): 291-301. https://doi.org/10.1007/BF01640412

HoYT, D.F. (1979): Practical Methods of Estimating Volume and Fresh Weight of Bird Eggs. The Auk 96: 73-77. https://doi.org/10.1093/auk/96.1.73

JÁNOSKA, F. (2016): Fácángazdálkodás - gondoljuk újra! Nimród 104(8): 6-7. (in Hungarian)

LEBLANC, Y. (1987): Intraclutch variation in egg size of Canada geese. Canadian Journal of Zoology 65(12):3044-3047. https://doi.org/10.1139/z87-461

MAgRATH, R.D. (1992): The effect of egg mass on the growth and survival of blackbirds: a field experiment. Journal of Zoology London 227: 639-653. https://doi.org/10.1111/j.1469-7998.1992.tb04420.x

Muller, H.D., NeILL, D.D. \& WeRnER, W.J. (1971): Reproducing, raising and releasing gray partridge. Colorado State University, Fort Collins, Colorado.

NilsSON, J.Å. \& SVENSSON, E. (1993): Causes and consequences of egg mass variation between and within blue tit clutches. Journal of Zoology 230: 469-481. https://doi.org/10.1111/j.1469-7998.1993.tb02699.x

OtwinOwsKa-Mindur, A., GuMUŁKA, M. \& KANIA-GIERDZIEwICZ, J. (2016): Mathematical models for egg production in broiler breeder hens. Annales of Animal Science 16(4): 1185-1198. https://doi.org/10.1515/aoas-2016-0037

PARSONS, J. (1976): Factors determining the number and size of eggs laid by the Hering Gull. The Condor 78: 481-492. https://doi.org/10.2307/1367097

PotTs, G. (1986): The partridge. Pesticides, predation and conservation. Blackwell Science, Oxford. 2016.

REID, W.V., AND BoERsma, P.D. (1990): Parental quality and selection on egg size in the Magellanic penguin. Evolution 44: 1780-1786. https://doi.org/10.1111/j.15585646.1990.tb05248.X

Shi, M., Fang, Y., ZhaO, J., Klaus, S., Jiang, Y., Swenson, J.E. \& Sun, Y-H. (2019): Egg laying and incubation rhythm of the Chinese Grouse (Tetrastes sewerzowi) at Lianhuashan, Gansu, China. Avian Research 10: 23. https://doi.org/10.1186/s40657$\underline{019-0161-X}$

Slagsvold, T., Sandvik, J., Rofstad, G., LoRentsen, Ö. \& Husby, M. (1984): On the adaptive value of intraclutch egg-size variation in birds. The Auk 101: 685-697. https://doi.org/10.2307/4086895

ST. CLAIR, C.C. (1996). Multiple mechanisms of reversed hatching asynchrony in Rockhopper Penguins. Journal of Animal Ecology 65: 485-494. https://doi.org/10.2307/5783

WiLliams, T.D. (1990): Growth and survival in Macaroni Penguin, Eudyptes chrysolophus, A- and B-chicks: do females maximise investment in the large B-egg? Oikos 59: 349354. https://doi.org/10.2307/3545145 
